\title{
Mitochondrial Mutation In Egyptian Patients With Type 2 Diabetes Mellitus.
}

\author{
Fawzi O,A*; Hassan Z,A*; Abdel Kawy S,I**; Al-Diwany O,I**; Adel \\ $\mathrm{A}, \mathbf{M}^{* *}$; Hassan A,A***. \\ Departments of Endocrinology* and Clinical pathology** Faculty of medicine for girls, \\ Otolaryngyology department $* * *$ Faculty of medicine (boys) -Al Azhar university.
}

\begin{abstract}
Mitochondrial gene mutation plays a role in the development of diabetes mellitus. An A to $\mathrm{G}$ substitution at base pair 3243 in the mitochondrial tRNAleu(UUR) gene (mt3243) is commonly associated with maternally inherited diabetes and deafness and other diseases. The aim of this study is to detect A to $G$ substitution at base pair 3243 in mitochondrial RNAleu(UUR) in the plasma of patients with type 2 diabetes mellitus, and to evaluate insulin sensitivity in all cases.

This study, included 41 patients (Group I, 31 cases with type 2 diabetes mellitus and maternal history of diabetes mellitus-and Group II, 10 cases with type 2 diabetes mellitus, bilateral SNHL, maternal history of diabetes mellitus with or without SNHL. Other10 healthy control group was included.

Patients and controls were subjected to full medical history and clinical examination. Serum measurements for liver and kidney function tests, fasting and postprandial blood glucose as well as C-peptide levels, in addition to lipid profile were collected. Audiological evaluation for all patients with SNHL was also done. Genetic investigation, for mDNA analysis, done by polymerase chain reaction restriction fragment length polymorphism (PCR-RFLP), to determine the mutation in the mitochondrial gene at position 3243 .
\end{abstract}

Results of the study showed that glycemic indices (FPG, 2hPPG and HbA1c), liver enzymes and blood urea were significantly higher among patient group compared to control group $(\mathrm{P}<0.05)$. There was no significant difference for values of creatinine and uric acid between cases and controls. Lipid profile was significantly higher among patient group compared to controls $(\mathrm{P}<0.05)$, except for HDL-C which was higher in controls however, it did not reach statistical significance. C-peptide values were not significantly different between studied groups. Age at onset of diabetes was relatively earlier in group II than group I. mDNA was present in all plasma samples of patients and controls. mDNA 3243 mutation was detected in the plasma of three patients with diabetes and SNHL with a rate of $7.3 \%$ of all diabetic patients and $30 \%$ of diabetic patients associated with deafness. The presence of mDNA mutation allowed 294 bp product to be cleaved into 180 and $114 \mathrm{bp}$ fragments and were seen as two bands.

In CoclusioN: The A $3243 \mathrm{G}$ mutation is present in Egyptian population and is considered as a cause of maternally inherited diabetes and deafness at a rate of $7.3 \%$ of all diabetic subjects and a rate of $30 \%$ of diabetics associated with deafness. mDNA mutation is present and detectable in plasma.

Maternally inherited diabetes and deafness differs pathophysiologically from the more common forms of type 2 diabetes in that, insulin resistance does not seem to be a major factor.

\section{Introduction}

The role of mitochondrial DNA (mtDNA) abnormalities in the development of diabetes has attracted recent widespread interest. Many mtDNA abnormalities have been described in association with diabetes, but the most commonly reported mutation 
is an A to $\mathrm{G}$ substitution at position 3243 in the tRNA ${ }^{\text {Leu (UUR) }}$ gene (Van den Ouweland et al., 1995).

Recent work has shown that the mutation also produces a characteristic phenotype of maternally inherited diabetes and sensorineural deafness (MIDD). Clinically, MIDD is typified by non- insulin dependent diabetes (type 2 diabetes) progressing relatively rapidly to insulindependent diabetes (Maassen and Kadowaki, 1996).

Insulin secretion requires normal mitochondrial respiratory chain function, and this has been shown to be impaired in tissues with the 3243 mutation (Van den Ouweland et al., 1992). This is supported by the demonstration that impaired insulin secretion is a key of metabolic feature of patients with MIDD (Kishimoto et al., 1995).

The use of plasma and serum as sources of genomic DNA for molecular diagnosis has raised interest because of its non-invasive nature and ease of sample collection. MtDNA and associated mutations are present and detectable in serum and plasma. Plasma and serum might be alternative sources for the molecular diagnosis of $\mathrm{mt} 3243$ associated diabetes mellitus, as well as other mitochondrial mediated diseases (Zhong et al., 2000). In the current study, the presence of mtDNA and the most common mt3243 mutation in plasma of patients with type 2 diabetes mellitus was investigated.

\section{Aim of the work}

- Detection of A to G substitution at base pair 3243 in mitochondrial RNA Reu (UUR) $^{\text {le }}$ in the plasma of patients with type 2 diabetes mellitus.

- Evaluation of insulin sensitivity in all cases.

\section{Subjects And Methods \\ This study comprised two main Egyptian groups: \\ Patient group: \\ Included 41 patients, their ages ranged from 40 to 72 years. They were classified into two subgroups:}

SUBGROUP I: comprised 31 patients with T2D, and maternal history of DM. Their ages ranged from (40-72) years.

SUBGROUP 2: comprised 10 patients with T2D, bilateral sensorineural hearing loss, family history of hearing impairment and/ or T2D. Their ages ranged from 40- 64 years.

Diabetic patients were diagnosed according to The Expert Committee on the Diagnosis and Classification of Diabetes Mellitus, 2003:

Control group: 10 healthy subjects, their ages ranged from 36 to 62 years, were included in this study. They were randomly selected. None of them had a positive family history of diabetes or hearing loss.

\section{Patients and controls were subjected to}

- Detiled history taking, laying stress on

- Hearing loss: Onset, course, and duration.

- Hearing aid, and consanguinity.

- Present history of trauma, fever, ear operation, noise, pain, tinnitus, vertigo ear discharge and headache.

All subjects with sensorineural hearing loss were evaluated audiologically.

The audiological evaluation included pure tone thresholds (air and bone). Only the range from 500 through $4000 \mathrm{~Hz}$ may be tested by bone conduction (Martin, 1994).

The audiological evaluation also consists of speech- threshold testing, which consists of two tests: Speech discrimination threshold (SDT) \& speech reception threshold (SRT (Martin, 1994).

The third test is the Imittencemetery which includes: Tympanometery, acoustic reflex, and the compliance of the tympanic membrane (Martin, 1994).

Laboratory investigations including:

1- Fasting and 2 hrs. postprandial plasma glucose level.

2- Liver function tests including AST, ALT.

3- Kidney function tests including, serum creatinine, urea and uric acid.

4- Lipid profile including cholesterol, triglycerides, HDL-C and LDL-C.

5- Complete blood count.

6- Fasting and 2 hrs. postprandial C-peptide 
7- Glycated hemoglobin.

8-Genetic Investigations: Mitochondrial DNA analysis and detection of point mutation was done by PCR-RELP.
Statistical Analysis: Coding of data was carried out manually and analysis was calculated through EPI-INFO statistical package.

Tests of Significance: $\mathrm{P}<0.05$ is significant.

\section{Results}

Table (1): Age, Biochemical \& Hormonal Parameters among studied groups

\begin{tabular}{|l|c|c|c|}
\hline & Patients & Controls & P value \\
\hline Age & $55.37 \pm 7.8$ & $52.8 \pm 12.3$ & $>0.05$ \\
\hline FBS & $190.5 \pm 92.3$ & $90.2 \pm 11.95$ & $<0.05$ \\
\hline PPBS & $256.2 \pm 123.9$ & $130.9 \pm 10.5$ & $<0.05$ \\
\hline HbA1c & $7.97 \pm 1.4$ & $4.8 \pm 0.5$ & $<0.05$ \\
\hline ALT & $25.7 \pm 18.97$ & $19.3 \pm 9.7$ & $<0.05$ \\
\hline AST & $26.2 \pm 15.95$ & $18.99 \pm 7.9$ & $<0.05$ \\
\hline UREA & $37.6 \pm 23.3$ & $24 \pm 5.7$ & $<0.05$ \\
\hline CREAT & $0.91 \pm 0.4$ & $0.8 \pm 0.2$ & $>0.05$ \\
\hline U.A. & $5.1 \pm 1.5$ & $4.6 \pm 0.9$ & $>0.05$ \\
\hline CHOL & $230.1 \pm 49.7$ & $185.3 \pm-44.9$ & $<0.05$ \\
\hline TG & $156.4 \pm 83.4$ & $109 \pm 60.5$ & $<0.05$ \\
\hline HDL & $49.6 \pm 13.3$ & $53.6 \pm 9.5$ & $<0.05$ \\
\hline LDL & $148.9 \pm 44.7$ & $112.8 \pm 39.6$ & $<0.05$ \\
\hline Hb & $12.6 \pm 1.4$ & $13.14 \pm 1.33$ & $>0.05$ \\
\hline Fast. C-peptide & $0.9 \pm 0.5$ & $0.7 \pm 0.5$ & $>0.05$ \\
\hline P.P. C-peptide & $2.4 \pm 1.6$ & $2.3 \pm 1.07$ & $>0.05$ \\
\hline
\end{tabular}

Table (2) Glycemic indices among diabetic groups compared to controls.

\begin{tabular}{|l|c|c|c|c|c|}
\hline & Control & \multicolumn{2}{|c|}{ Group 1 } & \multicolumn{2}{|c|}{ Group 2 } \\
\hline & Mean \pm SD & Mean \pm SD & P value & Mean \pm SD & P value \\
\hline FBS & $90.2 \pm 11.95$ & $179.7 \pm 69.3$ & $<0.05$ & $224.2 \pm 142.2$ & $<0.05$ \\
\hline PPBS & $103.9 \pm 10.5$ & $245.4 \pm 102.6$ & $<0.05$ & $289.9 \pm 177.5$ & $<0.05$ \\
\hline HbA1c & $4.8 \pm 0.5$ & $8.02 \pm 1.1$ & $<0.05$ & $7.8 \pm 1.9$ & $<0.05$ \\
\hline
\end{tabular}

Table (3): Lipid profile among diabetic groups compared to controls.

\begin{tabular}{|l|c|c|c|c|c|}
\hline & Control & \multicolumn{2}{|c|}{ Group 1 } & \multicolumn{2}{c|}{ Group 2 } \\
\cline { 3 - 5 } & Mean \pm SD & Mean \pm SD & P value & Mean \pm SD & P value \\
\hline Cholesterol & $185.3 \pm 44.9$ & $237.4 \pm 47.9$ & $<0.05$ & $207.5 \pm 50.4$ & $>0.05$ \\
\hline TG & $109 \pm 60.5$ & $164.1 \pm 89.1$ & $<0.05$ & $132.8 \pm 59.5$ & $>0.05$ \\
\hline HDL-C & $53.6 \pm 9.5$ & $51.5 \pm 14.5$ & $>0.05$ & $43.8 \pm 6.4$ & $>0.05$ \\
\hline LDL-C & $112.8 \pm 39.6$ & $152.8 \pm 44.7$ & $<0.05$ & $136.9 \pm 44.7$ & $>0.05$ \\
\hline
\end{tabular}

Table (4): Fasting and $2 \mathrm{hr}$ post prandial C- peptide among diabetic groups compared to controls.

\begin{tabular}{|l|l|l|l|l|l|}
\hline & Control & \multicolumn{2}{|c|}{ Group 1 } & Group 2 \\
\hline & Mean \pm SD & Mean \pm SD & P value & Mean \pm SD & P value \\
\hline Fasting C-peptide & $0.7 \pm 0.5$ & $0.9 \pm 0.5$ & $>0.05$ & $0.9 \pm 0.5$ & $>0.05$ \\
\hline P.P C-peptide & $2.3 \pm 1.07$ & $2.9 \pm 1.9$ & $>0.05$ & $2.3 \pm 1.07$ & $>0.05$ \\
\hline
\end{tabular}


Table (5): Degree of sensorineural hearing loss among patients of group 2 and all subjects of the study.

\begin{tabular}{|c|c|c|c|c|c|}
\hline & & \multicolumn{3}{|c|}{ Weakness of hearing } & \multirow{2}{*}{$\begin{array}{l}\text { Normal } \\
\text { hearing }\end{array}$} \\
\hline & No. & Mild & Moderate & Severe & \\
\hline Group 2 & 10 & $40 \%$ & $40 \%$ & $20 \%$ & $0 \%$ \\
\hline All subjects & 41 & $9.75 \%$ & $9.75 \%$ & $4.9 \%$ & $75.6 \%$ \\
\hline
\end{tabular}

Table (6): Rate of detection of mt DNA 3243 mutation by PCR technique among patients of the present study.

\begin{tabular}{|l|c|c|c|c|c|}
\hline & \multicolumn{2}{|c|}{} & \multicolumn{2}{|c|}{ PCR + ve } & \multicolumn{2}{c|}{ PCR -ve } \\
\hline & total & No. & $\%$ & No. & $\%$ \\
\hline Study subjects & 41 & 3 & 7.3 & 38 & 92.7 \\
\hline Group 1 & 31 & NIL & 0 & 31 & 100 \\
\hline Group 2 & 10 & 3 & 30 & 7 & 70 \\
\hline Control & 10 & NIL & 0 & 10 & 100 \\
\hline
\end{tabular}

Table (7): Rate of detection of mtDNA 3243 mutation by PCR technique as regards sex of the patients of the present study.

\begin{tabular}{|l|l|l|l|l|l|}
\hline & \multicolumn{3}{|l|}{} & PCR + ve & \multicolumn{2}{l|}{ PCR - ve } \\
\hline & Total & No. & $\%$ & No. & $\%$ \\
\hline Male & 18 & NIL & 0 & 18 & 100 \\
\hline Female & 23 & 3 & 13 & 20 & 87 \\
\hline
\end{tabular}

Figure (1): Electrophoretic separation of PCR amplified products separated on agarose gel and stained with ethidium bromide.

Lane 1 shows DNA marker was used for size determination: $[1353,1078,872,603,310,281,234,194,118,72]$

Lane $2,3,4$ represent controls

Lane 5 - 9 represent cases

Mitochondrial DNA was detected in all control and cases at $294 \mathrm{bp}$.

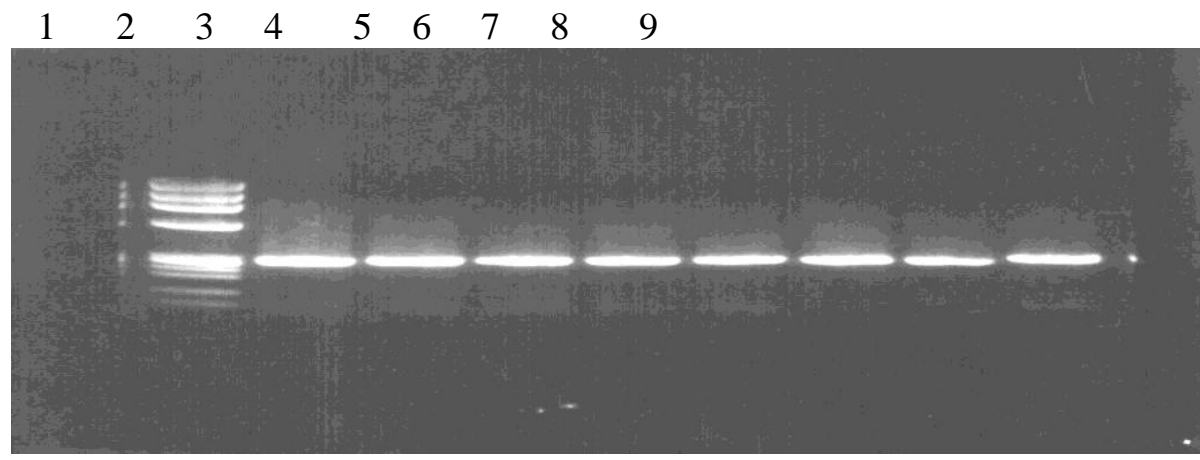


Figure (2): Electrophoretic separation of PCR amplified products separated on agarose gel and stained with ethidium bromide.

Lane 1 shows DNA marker was used for size determination: $[1353,1078,872,603,310,281,234,194,118,72]$

Lane 2 - 9 represent cases

Mitochondrial DNA was detected in all cases at $294 \mathrm{bp}$.

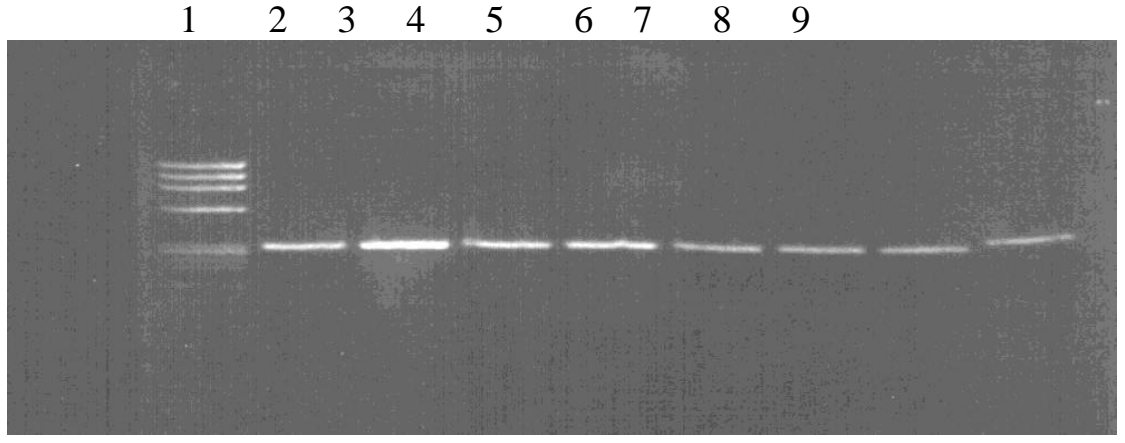

Figure (3): Electrophoretic separation of PCR amplified products separated on agarose gel and stained with ethidium bromide after restriction for 1 hour at $370 \mathrm{C}$ by Apa 1 enzyme.

Lane 1 shows DNA marker was used for size determination: $[2000,800,700,500,400,300,200,100]$

Lane 2 - 4 represent controls.

Lane 5-8 represent cases.

Mitochondrial DNA mutation was not detected "uncut at 294 bp" in all cases and controls.

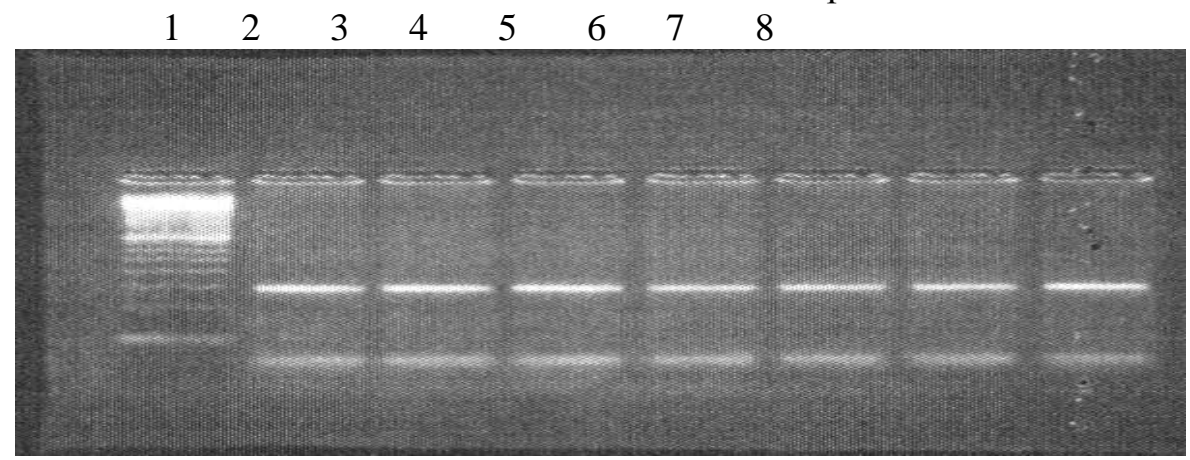


Figure (4): Electrophoretic separation of PCR amplified products separated on agarose gel and stained with ethidium bromide after restriction for 1 hour at 37oC by Apa 1 enzyme.

Lane 1 shows DNA marker was used for size determination: [2000,800,700,500,400,300,200,100]

Lane 2,6,7,8 represent -ve cases(uncut by Apa 1 giving one band at 294 bp).

Lane 3,4,5 represent +ve cases for 3243 mutation (Apa 1 cut mitochondrial DNA into two bands $180 \mathrm{bp}, 114 \mathrm{bp}$ ). The $114 \mathrm{bp}$ differ in its intinisty among the three +ve cases due to presence of heteroplasmy,

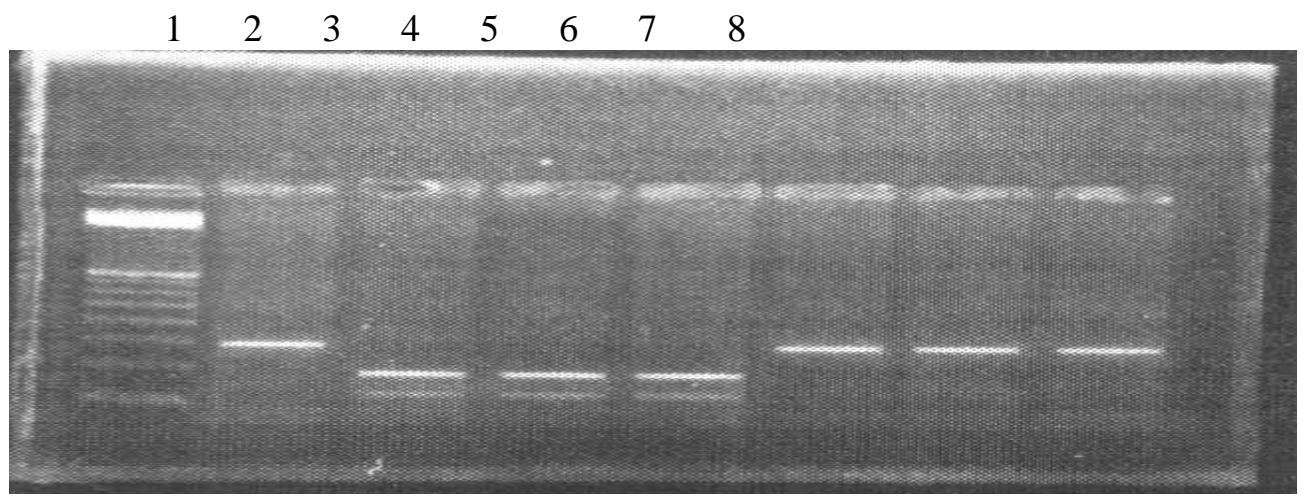

Table (8): Demographic and clinical characteristics of patients positive for mtDNA mutation.

\begin{tabular}{|l|l|}
\hline Characters & Positive mutant patients \\
\hline Sex & All were females \\
\hline Age & Ranged from 47-55 years. \\
\hline Maternal history of SNHL & Two of them had + ve history \\
\hline Age at onset of DM & Ranged from 39-45 years \\
\hline Age at onset of SNHL & Ranged from 42-49 years \\
\hline Degree of HL & Two had severe SNHL, one had mild degree \\
\hline Diabetic therapy & $\begin{array}{l}\text { Two were treated by insulin inj., the other one was treated with } \\
\text { oral hypoglycemic agents }\end{array}$ \\
\hline Hearing aid & All had hearing aid. \\
\hline Renal insufficiency & One had renal insufficiency \\
\hline History of visual affection & One had retinopathy \\
\hline Obesity & Two were overweight and one had normal weight \\
\hline Glycemic control & $\begin{array}{l}\text { One was good controlled, one was fair controlled, and the last was } \\
\text { poor controlled }\end{array}$ \\
\hline Pregnancy & $\begin{array}{l}\text { One had history of still birth and the other two had normal } \\
\text { pregnancy }\end{array}$ \\
\hline
\end{tabular}

\section{Discussion}

Mitochondrial DNA is predominantly inherited maternally. In 1992, Van den
Ouweland described several families with a maternal inheritance pattern of diabetes, 
sensorineural deafness, or both, as well as a mitochondrial mutation (Van den Ouweland et al., 1992).

Among many mutations in mtDNA, the $\mathrm{A} 3243 \mathrm{G}$ mutation is known to somatically accumulate with age. The accumulation of the mutation in pancreatic beta cells may cause adult-onset diabetes mellitus (Kadowaki et al., 1994).

Nerve deafness is present in the majority of the cases with maternally inherited diabetes and deafness, MIDD, but may be of slight degree that it is not even noticed or observed, and its onset may be years later than the diabetes. Therefore, despite the fact that deafness is an important hallmark of the disease, Type 2 DM may yet be the only clinical manifestation for a rather long period of time in its whole course (Kunsan et al., 1997).

Mitochondrial deafness is generally caused by homoplasmic mutations, and yet the severity of hearing impairment varies from profound congenital hearing loss to no hearing loss at all; in addition, the mutations affect only the cells in the inner ear. It has been shown in man and mouse that the onset and severity of hearing loss depend both on environmental factors, such as exposure to aminoglycosides, and several nuclear genes (Johnson et al., 2001).

In the present study, glycemic indices (FPG, 2 hr. PPG and $\mathrm{Hb}$ Alc) were significantly higher among both patient groups compared to control group $(\mathrm{P}<0.05)$. However, glycemic indices were higher in group 2 than in group 1.

Liver enzymes were significantly higher among both patient groups compared to control group $(\mathrm{P}<0.05)$. Raised liver enzymes in these patients may be due to liver diseases occurring as a consequence of diabetes mellitus.

Values of blood urea were significantly higher among diabetic subjects compared with controls $(\mathrm{P}<0.05)$. Serum creatinine values were also higher but didn't reach statistical difference. This signifies the evolution of diabetic nephropathy among the patient groups

Serum uric acid values were also higher among patient groups compared to controls but didn't reach statistical difference.

In the present study, CBC was done for diabetic patients and control group. Although there was no significant difference between patients and controls in hemoglobin level, there were 6 females of both patient groups who had hemoglobin level below $12 \mathrm{~g} / \mathrm{dl}$ and 3 males of both patient groups who had $\mathrm{Hb}$ level below 13 $\mathrm{g} / \mathrm{dl}$.

In the current study, values of cholesterol, triglycerides and LDL-C were higher in group 1 and 2 compared to controls $(\mathrm{P}<0.05)$. This increase reached statistical significance only for group 1 . HDL-C was higher in controls but it didn't reach statistical significance.

Several lipid abnormalities are found in patients with type 2 diabetes. Triglycerides and triglyceride-rich lipoprotein levels are usually about 1.5-3 times greater than in nondiabetic patients matched for age, sex, and body mass index (Taskinen, 1997).

There was no statistically significant difference between case groups and controls $(\mathrm{P}>0.05)$ as regards levels of $\mathrm{C}$-peptide of insulin. Type 2 diabetes is a consequence of insulin resistance with compensatory hyperinsulinemia. However later in the process B-cell failure evolves with consequent normal or even decrease of insulin level.

In addition oral hypoglycemic agents with whom most diabetics treated with, lead to stimulatation of B-cell secretion of insulin (Boden, 1997).

When measuring BMI for the studied patients in the current study $58.6 \%$ were obese (BMI>30). Obesity in group 1 was more than in group 2 . There were $24.4 \%$ overweight (BMI>24). Only $17 \%$ of all cases were normal weight $(\mathrm{BMI}<24)$.

In the present study we estimate glycated hemoglobin to assess glycemic control. $54.8 \%$ of diabetic patients were poorly controlled, while $25.8 \%$ were fairly controlled. Only $19.4 \%$ of patients from both groups were good controlled.

These results were agreed with the high rate of history of complications given by patients of both group. 
Genetic investigations carried out by PCR amplification of the mtRNA ${ }^{\text {Leu(UUR) }}$ region in mitochondrial DNA (mtDNA) in plasma samples, revealed the presence of mtDNA in all samples of patients and controls.

After ApaI digestion of the amplified DNA fragments, mt3243 was detected in the plasma samples of three patients with diabetes and SNHL. None of the plasma samples from the healthy subjects or those patients from group 1 had this mutation.

The presence of mt 3243 allowed the $294 \mathrm{bp}$ product to be cleaved into 180 and $114 \mathrm{bp}$ fragments and were seen as two bands.

The rate of mtDNA mutation in the present study, was $7.3 \%$ among both groups and $30 \%$ of group 2. Other researchers screened the routine hospital diabetic population reported that the prevalence of mitochondrial diabetes ranged from 1-3\% of all diabetic patients ( Kumiko et al., 2001).

Newkirk et al., 1997 have screened carefully selected diabetic populations and have reported MIDD prevalence rates ranging from undetectable to $60 \%$. A total of 1440 patients (type 1 and 2) of North European attending two hospital diabetes services were screened by questionnaire. This identified 445 patients with one or more features of MIDD and/or MELAS and these subjects were then genotyped. Two patients were identified with the mutation giving a prevalence rate of $0.13 \%$ for whole study population, Newkirk et al., concluded that 3243 mutation is rare in the routine hospital diabetic population.

Moreover Saker et al., 1997 assessed the prevalence of this mutation in newly diagnosed diabetic subjects, two of 748 $(0.27 \%)$ type 2 diabetic subjects with a family history of diabetes were found to possess the mutation. These subjects had early onset of diabetes and were nonobese. One patient was not deaf, and the other was deaf. They stated that the 3243 mutation occurs in only approximately $0.1-0.2 \%$ of white Caucasian Type 2 diabetic patients in the United Kingdom.

In a mass screening of Japanese patients done by (Liou et al., 2000) with familial type $2 \mathrm{DM}$, about $2.8 \%$ of the patients were found to carry the A3243G point mutation.

Kumiko et al., 2001 investigated 240 unrelated Japanese with diabetes mellitus (188 with type $2 ; 39$ with type $1 ; 13$ with gestational diabetes). The A3243G mutation was found in seven patients (one male and six females). The ages of the patients diagnosed to have A3243G mutations were 29-62 years. All patients showed hearing loss. The prevalence of this mutation was $2.9 \%$, and this finding correlates with reports that the prevalence was within a range of $1-3 \%$ in Japanese diabetic populations.

The high percentage of $\mathrm{mt}$ mutation in the present study relied on that, more than one criterion have been taken into consideration as, maternal history of both DM and of deafness, and selected patients with bilateral SNHL and Type 2 DM. This was in agreement with the work done by Kunsan et al., 1997, who calculated the prevalence of A3243G mutation to be $11.1 \%$. They reported the results of screened 207 Chinese Type 2 DM patients and pedigree analysis of the positive cases in which hearing impairment was present in most of them. They reported the prevalence to be $0.5 \%$.

In the present study, the three patients, were all females who had type 2 diabetes \& SNHL. They had different degree of SNHL, one of them had mild degree of HL and the other two had severe degree of HL. All were using hearing aid. They were diagnosed with hyperglycemia between the ages of 39 and 45 years for the first time. The one who maintained relatively good insulin secretion (her C-peptide level was normal) had only undergone drug therapy with oral hypoglycemic agents. The remaining two patients became diabetic for a longer duration, their C-peptide levels were low thus they have been treated with insulin. Fasting and $2 \mathrm{hr}$ postprandial CPeptide values estimated for the three patients raised the possibility of absence of hyperinsulinaemia associating insulin resistance.

Previously, in a population study of diabetic patients with the A3243G mutation, 
Kadowaki and coworkers found that 27 of 44 patients also had sensorineural hearing loss (Kadowaki et al., 1994).

The article by Guillausseau and colleagues confirms in a relatively large cohort of patients with maternally inherited diabetes and deafness (MIDD) that the diabetes phenotype in this syndrome is quite different from that in other known forms of diabetes (Guillausseau et al., 2001).

Shin et al., 1998 studied the prevalence of 3243 mutation in Korea, They screened 433 Korean diabetic patients. Five patients showed mitochondrial mutations, two had 3243 mutation and three had 3426 mutation. None of the 5 patients had deafness. The two diabetic patients were lean, had lower fasting C-peptide concentrations, and required insulin for management. They found that the prevalence of 3243 mutations in Korean diabetic patients was approximately $0.5 \%$.

Maasen, 2002 noted that, most of the patients who develop diabetes have an impaired hearing due to reduced detection of high tone frequencies present in the majority of diabetic patients.

The clinical importance of the raised mt3243 in patients' plasma or serum is worthy of investigation, it might correlate with active disease staging or responses to stress or drug administration. In the latter case, serum and plasma mt3243 measurements might be potential markers of drug efficacy if drugs are developed to interfere with the relative growth of wild-type and mutation carrying mitochondria in the future (Mulcahy et al., 1996).

IN Conclusion: The A3243G mutation is present in Egyption population and considered as a cause of Maternally Inherited Diabetes and Deafness at a rate of $7.3 \%$ of all diabetic subjects and a rate of $30 \%$ of diabetics associated with deafness. Mt DNA 3243 mutation is present and detectable in plasma. Plasma and serum might be alternative sources for the molecular diagnosis of $\mathrm{mt} 3243$ associated diabetes mellitus, as well as other mitochondrial mediated diseases.

Maternally inherited diabetes and deafness differs pathophysiologically from the more common forms of type 2 diabetes mellitus in that, insulin resistance does not seem to be a major factor.

\section{References}

1. Boden G., (1997): Role of fatty acids in the pathogenesis of insulin resistance and NIDDM [published erratum appears in Diabetes 1997 Mar; 46(3):536]. Diabetes 46:3-10.

2. Guillausseau PJ, Massin P, DuboisLaForgue D, et al., (2001): Maternally inherited diabetes and deafness: a multicenter study. Ann Intern Med.; 134:721-8.

3. Johnson KR, Zheng QY, Bykhovskaya Y, et al., (2001): A nuclear-mitochondrial DNA interaction affecting hearing impairment in mice. Nat Genet.; 27:191-4.

4. Kadowaki T., Kadowaki H., Mori Y., et al., (1994): A subtype of diabetes mellitus associated with a mutation of mitochondrial DNA. N Engl J Med 330:962-968.

5. Kishimoto M., Hashiramoto M., Araki S., et al., (1995): Diabetes mellitus carrying a mutation in the mitochondrial tRNA leu(UUR) gene. Diabetologia, 38: 193-200.

6. Kumiko O., Akemi Y., Mariko N., et al., (2001): Mitochondrial Gene Mutations in the tRNA ${ }^{\text {Leu(UUR) }}$ Region and Diabetes: Prevalence and Clinical Phenotypes in Japan Clinical Chemistry, 47:1641-1648.

7. Kunsan X., Yanqing W., and Songhua W., (1997): Mitochondrial t RNA gene mutation diabetes mellitus in Chinese. Chinese Medical J., 110(5): 372-378.

8. Liou CW., Auang CC., and Tsai JL., (2000): Case report. Absence of maternal A3243G mt DNA mutation and reversible hyperglycemia in a patient with MELAS syndrome. Acta Neurol Scand., 101: 65-69.

9. Maassen JA. and Kadowaki T. (1996): Maternally inherited diabetes and deafness: a new Diabetes subtype. Diabetologia, 39: 375-382.

10. Maassen JA., (2002): Mitochondrial diabetes: pathophysiology, clinical presentation, and genetic analysis. Am. J. Med. Genet. May 30;115(1):66-70.

11. Martin F.N., (1994): Introduction to audiology, 6 th (ed.) Englewood Cliffs. Prentice Hall, New Jersey.

12. Mulcahy HE., Croke DT., and Farthing MJG., (1996): Cancer and mutant DNA in blood plasma. Lancet; 348:628.

13. Newkirk J.E., Taylor R.W., and Howell N., (1997): Maternally inherited diabetes 
and deafness: Prevalence in a hospital diabetic population. Diabetic Medicine, 14: 457-460.

14. Saker PJ., Hattersley AT., Barrow B., et al., (1997): Low prevalence of the mitochondrial transfer RNA gene (tRNA leu(UUR)) mutation at position $3243 \mathrm{bp}$ in UK Caucasian Type 2 diabetic patients. Diabetic Medicine, 14: 42-45.

15. Shin CS., Kim SK., and Park KS., (1998): A new point mutation (3426, A to $\mathrm{G})$ in mitochondrial NADH dehydrogenase gene in Korean diabetic patients which mimics 3243 mutation by restriction fragment length polymorphism pattern. Endocrine J., 45(1), 105-110.

16. Taskinen M-R., (1997): Triglyceride is the major atherogenic lipid in NIDDM. Diabetes/Metabolism Reviews, 13: 93-8.

17. The Expert Committee on the Diagnosis and Classification of Diabetes Mellitus (2003): Report of the Expert Committee on the Diagnosis and Classification of Diabetes Mellitus. Diabetes Care, 26:S5S20.

18. Van den Ouweland JMW., Lemkes HHPJ., Gerbitz KD., et al., (1995): Maternally inherited diabetes and deafness (MIDD): a distinct subtype of Diabetes and deafness associated with a mitochondrial tRNA leu(UUR) gene Point mutation. Muscle and Nerve, s3: s124-s130.

19. Van den Ouweland JMW., Lemkes HHPJ., Ruitenbeek W., et al., (1992): Mutation in mitochondrial tRNA leu(UUR) gene in a large pedigree with maternally transmitted Type $2 \mathrm{DM}$ and deafness. Nature Genet., 1: 368-371.

20. Zhong S., Maggie C. Y. N., Dennis L., et al., (2000): Presence of mitochondrial tRNA ${ }^{\text {Leu(UUR) }}$ A to G 3243 mutation in DNA extracted from serum and plasma of patients with type 2 diabetes mellitus J. Clin. Pathol; 53:466-469. 


\section{التحور الجيني للميتوكوندريا في المرضى المصريين المصابين}

\section{بمرض السكر من النوع الثاني}

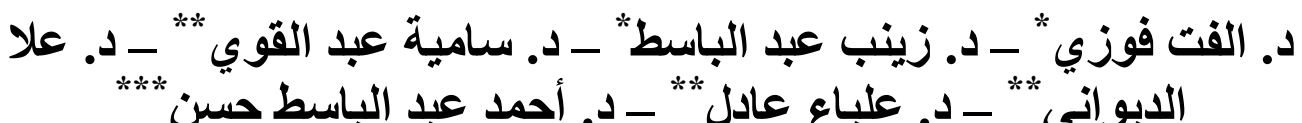

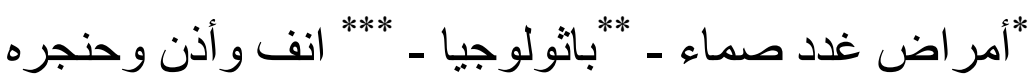

كلية طب الازهر *، ** بنات ـ *** بنين )

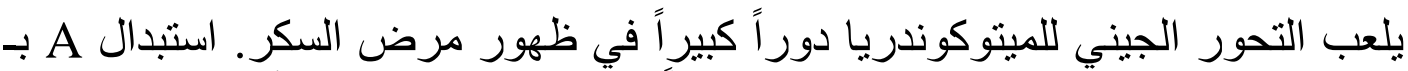

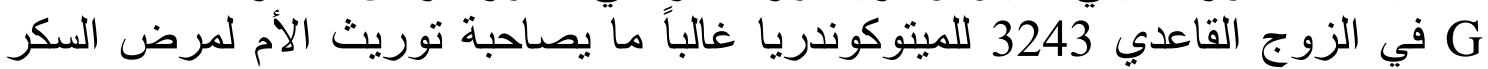

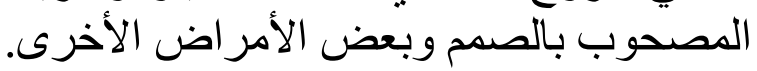

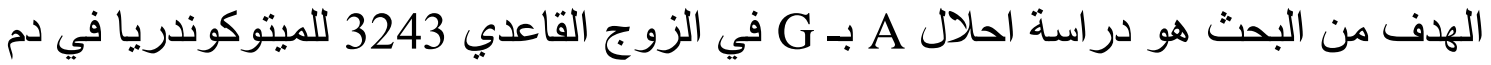

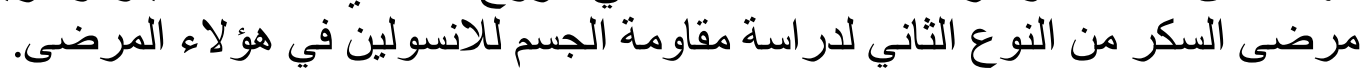

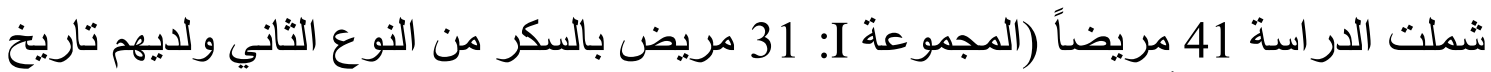

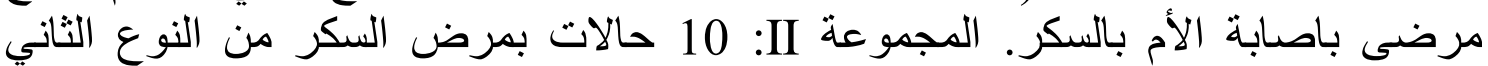

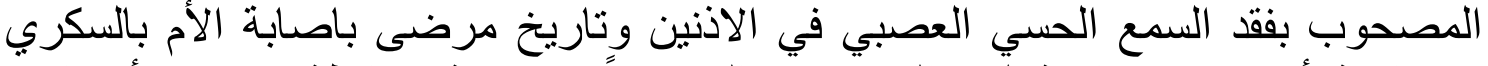
بمصاحبة أو عدم مصاحبة لقفد السمع. ووهناك اليضاً مجموعة ضاريطة من 10 أشخاص اصحاء.

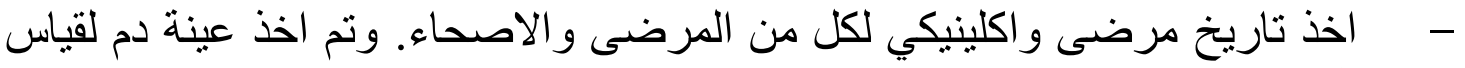

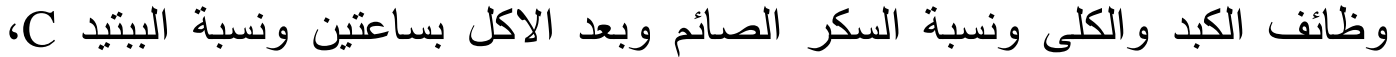

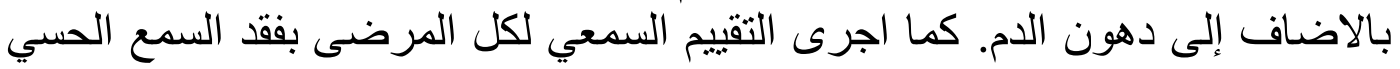

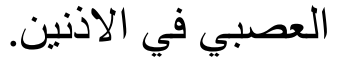

أيضاً تم عمل دراسات جينية لل m DNA لاختبار التحور الجيني للميتوكوندريا في

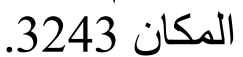

اظهرت نتائج البحث أن معدلات السكر ووظائف الكبد و الكلى ودهون الدم بالجسم

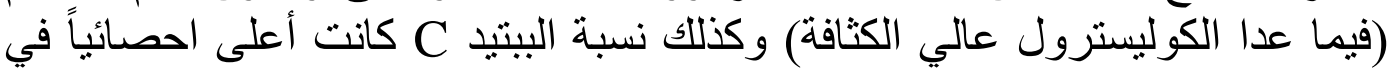
المرضى مقارنة بالمجمو عة الضابطة.

تاريخ ظهور المرض في المجموعة II كان في سن اصغر مقارنة بالمجموعة II. كانت موجودة في المرضى و الاصحاء، أما التحور الجيني للميتوكوندريا

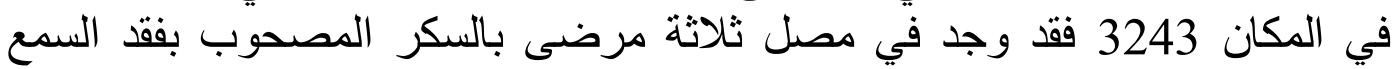

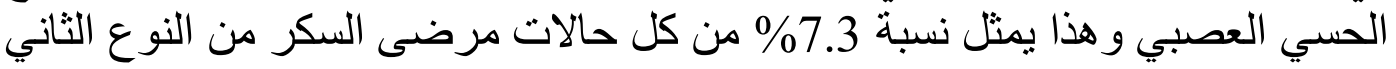
ونسبة 30\% من مرضى السكر المصحوب بفقد السمع. 
الخلاصة:-

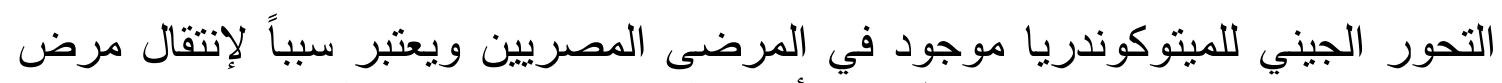

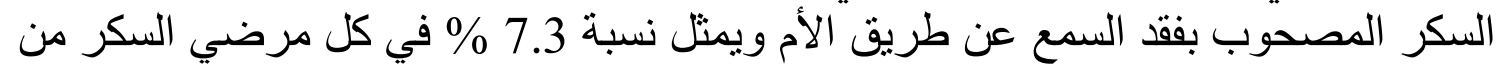

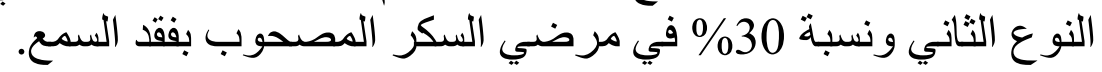
التحور الجيني موجود ويمكن قياسه في المصل.

يختلف مرض السكر المصحوب بفقد السمع المُورث من ناحية الأم عن مرض السكر من لئن النوع الثناني في أن مقاومة الجسم للانسولين ليست ظاهرة الفراسية فيه. 